\title{
Design and Manufacture of Pottery Dripper for the Use of Saline Water in Irrigation Systems
}

\author{
Mohamed El-Sayed El-Hagarey \\ Soil Conservation and Water Resources Dept., Desert Research Center, Egypt. \\ Corresponding author, elhagarey@gmail.com
}

\begin{abstract}
Pottery dripper was designed and manufactured to allow the use of saline water in irrigation systems. In Egypt, 2 to 3 thousand million $\mathrm{m}^{3}$ of saline water are used in the irrigation of about 405000 ha of land. The main objectives of this study are: (1) Invent a new pottery dripper to reduce saline water concentration; (2) manufacture and evaluate a pottery dripper. Pottery dripper dimensions are designed in three volumes (49, 31.4 and $\left.16.5 \mathrm{~cm}^{3}\right)$, three nominal porosity $(10,21$ and $31 \%)$; then various types of pottery drippers (PD) are tested under three pressure heads (1,0.75 and 0.5 bar) and three concentrations of saline groundwater (6154, 7149 and 7154 ppm), from Ras-Sudr Research Station.

The main results of this study showed the following:

For porosity $P_{1}(10 \%)$ of pottery dripper, under operating pressure head 1 bar, the discharge ranged from 0.5 $\mathrm{l} / \mathrm{s}$ to $1.14 \mathrm{l} / \mathrm{s}$; under operating pressure head $0.75 \mathrm{bar}$, the discharge ranged from $0.5 \mathrm{l} / \mathrm{s}$ to $1.14 \mathrm{l} / \mathrm{s}$; and under operating pressure head 0.5 bar, the discharge ranged from $0.2 \mathrm{l} / \mathrm{s}$ to $0.53 \mathrm{l} / \mathrm{s}$.

For porosity $P_{2}(21 \%)$ of pottery dripper, under operating pressure head 1 bar, the discharge ranged from 1.69 l/s to $4.11 \mathrm{l} / \mathrm{s}$; under operating pressure head 0.75 bar, the discharge ranged from $1.14 \mathrm{l} / \mathrm{s}$ to $3.06 \mathrm{l} / \mathrm{s}$; and under operating pressure head $0.5 \mathrm{bar}$, the discharge ranged from $0.58 \mathrm{l} / \mathrm{s}$ to $1.82 \mathrm{l} / \mathrm{s}$.

For porosity $P_{3}(31 \%)$ of $P D$, under operating pressure head 1 bar, the discharge ranged from 24.1/s to 37.7 l/s; under operating pressure head 0.75 bar, the discharge ranged from $16.8 \mathrm{l} / \mathrm{s}$ to $28.3 \mathrm{l} / \mathrm{s}$; and under operating pressure head 0.5 bar, the discharge ranged from $9.5 / \mathrm{s}$ to $19.4 \mathrm{l} / \mathrm{s}$.

Saline water concentration decreased from $6154 \mathrm{ppm}$ to 5840, 5806 and 5440ppm using the PD with porosity 10,21 and $31 \%$ respectively. Saline water concentration decreased from 7149ppm to 7106, 7013 and $6979 \mathrm{ppm}$ using the PD with porosity 10,21 and 31\% respectively; and finally saline water concentration decreased from 7863 ppm to 7846, 7778 and 7285 ppm using the PD with porosity 10, 21 and $31 \%$ respectively,
\end{abstract}

Keywords: Pottery-dripper, Saline-Water, Drip irrigation, Design, Flow, Pressure, Porosity

\section{Introduction}

Pottery dripper was designed and manufactured to allow the use of saline water in irrigation systems. In Egypt, 2 to 3 thousand million $\mathrm{m}^{3}$ of saline water are used in the irrigation of about 405000 ha of land. The main objectives of this study are: (1) invent a new pottery dripper to reduce saline water concentration; (2) manufacture and evaluate a pottery dripper. Bhatt et al. 2013 found out that pitchers technique could be successfully employed at places where salinity and alkalinity constitute a problem. Salt deposition on the wall of pitchers does not adversely affect the plant growth as the plants continue to draw water from the pitchers. There is a high degree of correlation between the rate of water diffusion through small pitchers and large pitchers. Use of small-sized pitchers was more beneficial both in terms of water saving and in economic terms when compared to large pitchers. Vasudaven $\boldsymbol{e t}$ al. 2011 indicated that daily depletion (\%) from buried pitchers has slightly decreased with time. Mean daily depletion (\%) has also decreased with the increase in salinity of the salt water taken. Salt distribution in soil around the pitcher has increased with the increase in horizontal distance from pitcher and decreased on moving vertically downwards. Salinity of residual water in pitchers has increased with time showing that these pitchers have the capability to retain water. Mathai and Simon 2004 concluded that water diffusion is more consistent with respect to the organic matter-mixed pottery samples rather than the sand-mixed ones. Uniform porosities of organic matter-mixed pottery discs, as evidenced by optical micrographs, further exemplify that. Pots/pottery sheets produced through this process can thus be used to control water release in pitcher irrigation of tree saplings. Batchelor $\boldsymbol{e t}$ al. 1996 reached some results as far as the pitcher irrigation and subsurface irrigation using clay pipes are concerned. It was proved that subsurface irrigation using clay pipes were particularly effective in improving yields, crop quality and water use efficiency as well as being cheap, simple and easy to use. Siyal and Skaggs, 2009 showed through computer simulations with HYDRUS (2D/3D), that with the increase in the pressure head in the irrigation pipe, the size of the wetted zone also increases. The depth of pipe installation affects the recommended spacing between laterals, although the use of shallow installations can lead to higher evaporative losses. For a given water application, the potential rate of surface evaporation affects the shape of the wetted region only minimally. Soil texture, due to its 
connection to soil hydraulic conductivity and water retention, has a larger impact on the wetting geometry. In general, greater horizontal spreading occurs in fine texture soils, or in the case of layered soils, in the finer textured layers.

\section{Material and Methods}

Pottery dripper (PD) are designed and manufactured from local and environmental materials where the basic component of PD is pottery discs. It is made from various mixtures, porosity, and volumes. The mixtures contain organic matter (saw dust) by 10,21 and 31\% total mix weight. The basic element of mixes is Aswan clay. Pottery discs are used in designed poly-ethylene dripper to protect and service the pottery discs for basic jobs (dripping and reducing the saline water concentration). Fig.1.
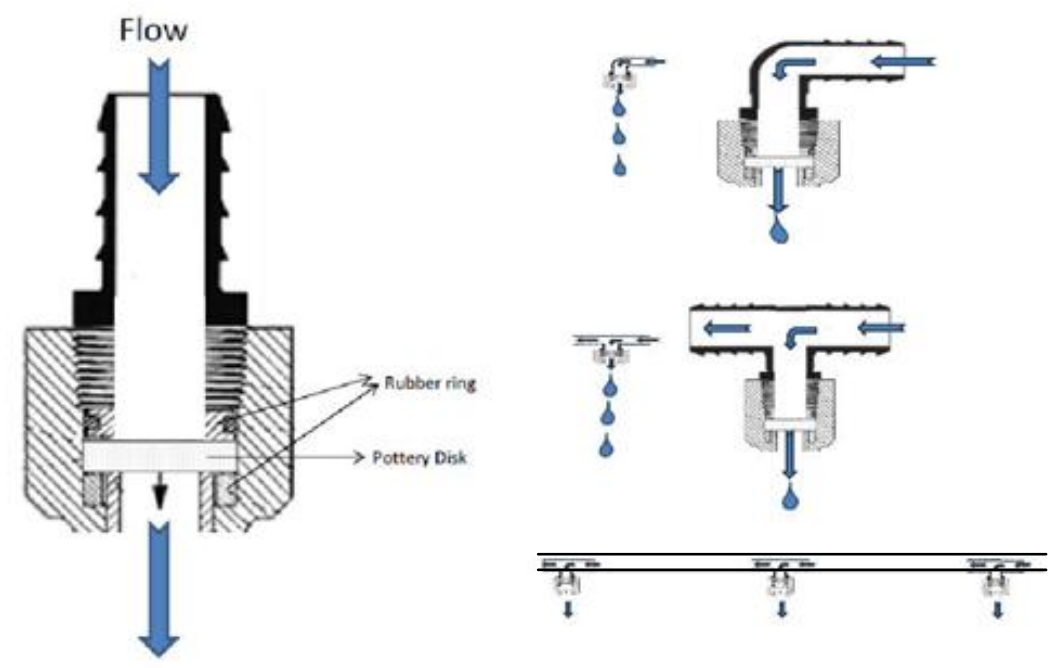

Fig. 1 Schematic diagram shows the design of pottery dripper.

Pottery dripper dimensions are designed in three volumes and three porosity, then various types of pottery drippers are tested under three pressure heads $(0.5,0.75$ and 1 bar) and three concentrations of saline groundwater $(6154,7149$ and $7863 \mathrm{ppm})$.

\section{Factor study:}

1- Pottery discs porosity, according to organic matter (saw-dust) percentage in pottery mixture $(5,10$, and $15 \%$ from mixture weight).

2- Pottery discs volumes, $\left(49,31.4\right.$ and $\left.16.5 \mathrm{~cm}^{3}\right)$, discs diameter $3.5,2.8$ and $2 \mathrm{~cm}$, thickness $5 \mathrm{~cm}$.

3- Operation head $(0.5,0.75$ and 1 bar $)$, and

4- Three different water concentrations will be used in pottery drippers test $(6154,7149$ and $7149 \mathrm{ppm})$.

\section{Measurements and calculation:}

\section{Hydraulic characteristics:}

1- Evaluate pottery drippers flow performance under three operation heads $(0.5,0.75$ and 1 bar), where discharge is determined by received water application at graded container during a period of time according to Keller and Karmeli (1975).

\section{Hydraulic laboratory:}

Laboratory experiments were conducted at Hydraulic Laboratory of Desert Research Center, to test and evaluate the hydraulic characteristics of pottery drippers (PD) with three disc diameters 3.5, 2.8 and $2 \mathrm{~cm}$, thickness 5 $\mathrm{cm}$. testing under pressure head ranged between $5-10 \mathrm{~m}$.

\section{- Experimental apparatus:}

The laboratory testing equipment contained an electrical centrifugal pump linches $/ 1.5$ inches $(25-56 \mathrm{~m}$ pressure head, $6.6 \mathrm{~m} 3 / \mathrm{h}$ discharge, $1.5 \mathrm{~kW}$, and $2860 \mathrm{rpm})$, pressure gauges $(10 \mathrm{~cm}$ smallest reading), Manometer, control valves, and water container. Fig. (2). 


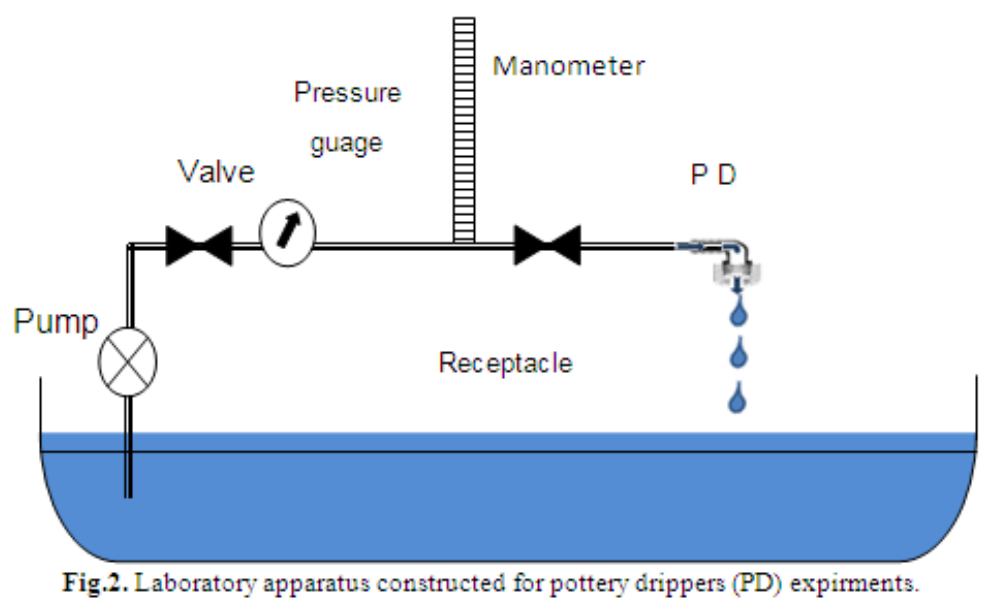

Hydraulic measurements include drippers discharge and operating pressure head, measurements for various types of designed nozzles were conducted. And received water salinity after pottery dripper was measured by EC Meter and so before pottery dripper.

\section{Physical characteristics:}

1- Take a photo of pottery disc surface by Optical micrograph and scanning electron microscope (SEM).

2- Determine Water absorption (\%), Bulk density $\left(\mathrm{g} / \mathrm{cm}^{3}\right)$, Drying deflators $(\%)$, burning deflators $(\%)$, and Total deflators $(\%)$.

3- XRD analysis for three type of pottery mixture at $\mathrm{X}$ ray lab beside other measurements in National Center for Housing and Building Research, Egypt.

\section{Results and discussion}

Reducing water concentration versus pottery volume and porosity:

Data as shown in Table.1. illustrates that saline water concentration is reduced after using pottery drippers. Saline water with concentration $\mathrm{C}_{1}(6154 \mathrm{ppm})$ is reduced to $5440 \mathrm{ppm}$. This indicates that concentration has been reduced by $714 \mathrm{ppm}$ due to the use of pottery with the smallest porosity percentage (10\%). Thereupon, water concentration shall decline to $5806 \mathrm{ppm}$ and 5806 and 5840 for pottery porosity 21 and $31 \%$ respectively.

Table.1. Effect of pottery discs volume and porosity on TDS.

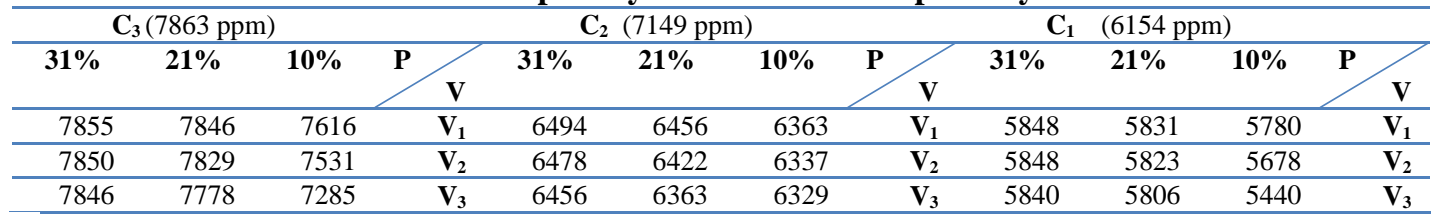

Where:

$$
\begin{aligned}
& \text { P: Porosity percentage }(\%) \text {, } \\
& \text { C: } \quad \text { Saline water concentration (ppm). }
\end{aligned}
$$

V: Pottery disc volume $\left(\mathrm{cm}^{3}\right)$, and

This is the result for the biggest volume of pottery discs $\left(49 \mathrm{~cm}_{3}\right)$. Volume $31.4 \mathrm{~cm}^{3}$ for pottery discs reduces water concentration but not like the biggest volume $49 \mathrm{~cm}^{3}$, where water concentration declines from $6154 \mathrm{ppm}$ to 5678,5678 and $5848 \mathrm{ppm}$ for pottery porosity 10, 21 and $31 \%$ respectively. However, the smallest volume of pottery discs $\left(16.5 \mathrm{~cm}^{3}\right)$ is the least effective in reducing saline water concentration, where water concentration declines from $6154 \mathrm{ppm}$ to 5780,5831 and $5848 \mathrm{ppm}$ by using pottery discs porosity 10,21 and $31 \%$ respectively. These findings show that that the decline of saline water concentration is directly proportional to volumes of pottery discs and inversely proportional to pottery porosity percentage, as shown in Fig.3. 


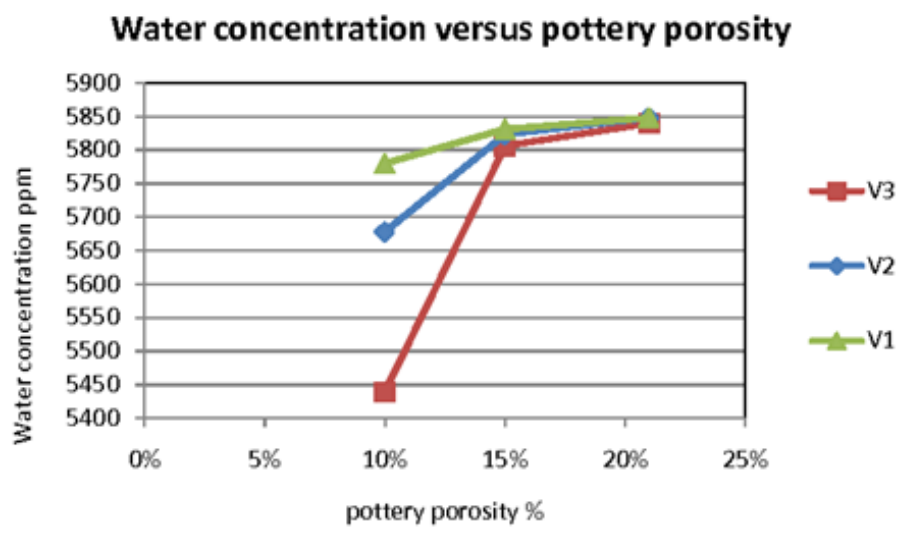

Fig. 3 Effect of pottery dripper porosity of water total dissolved salts (6154 ppm).

Saline water with concentration $\mathrm{C}_{2}(7149 \mathrm{ppm})$ is reduced to $6329 \mathrm{ppm}$. This indicates that concentration shall be reduced by $650 \mathrm{ppm}$ for using pottery with the smallest porosity percentage $(10 \%)$. Water concentration shall decline to 6363 and 6456 for pottery porosity 21 and $31 \%$ respectively. This applies to the biggest volume of pottery discs $\left(49 \mathrm{~cm}_{3}\right)$. Volume $31.4 \mathrm{~cm}^{3}$ for pottery discs reduces water concentration from $7149 \mathrm{ppm}$ to 6337,6422 and $6478 \mathrm{ppm}$ for pottery porosity 10, 21 and $31 \%$ respectively. However, the smallest volume of pottery discs $\left(16.5 \mathrm{~cm}^{3}\right)$ is the least effective in reducing saline water concentration, where water concentration has reduced from $7149 \mathrm{ppm}$ to 6363,6556 and $6494 \mathrm{ppm}$ by using pottery discs porosity 10, 21 and $31 \%$ respectively. This clearly demonstrates that reduction of saline water concentration is directly proportional to volumes of pottery discs and inversely proportional to pottery porosity percentage, as shown in Fig.4.

Saline water with concentration $\mathrm{C}_{3}(7863 \mathrm{ppm})$ is reduced to $7285 \mathrm{ppm}$. This indicates that concentration shall be reduced by $578 \mathrm{ppm}$ for using pottery with the smallest porosity percentage (10\%).

\section{Water concentration versus pottery porosity}

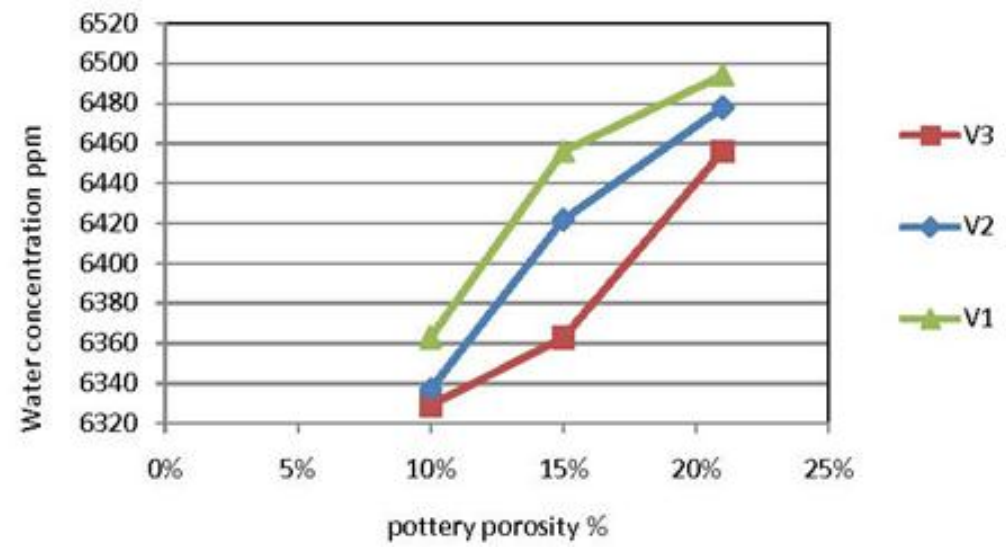

Fig. 4 Effect of pottery dripper porosity of total dissolved salts (7149 ppm).

Thereupon, water concentration shall decline to 7778 and $7846 \mathrm{ppm}$ for pottery porosity 21 and $31 \%$ respectively. This applies to the biggest volume of pottery discs $\left(49 \mathrm{~cm}_{3}\right)$. Volume $31.4 \mathrm{~cm}^{3}$ for pottery discs reduces water concentration from $7863 \mathrm{ppm}$ to 7531,7829 and $7850 \mathrm{ppm}$ for pottery porosity 10,21 and $31 \%$ respectively. However, the smallest volume of pottery discs $\left(16.5 \mathrm{~cm}^{3}\right)$ is the least effective in reducing saline water concentration, where water concentration is reduced from $7863 \mathrm{ppm}$ to 7616,7846 and $7855 \mathrm{ppm}$ by using pottery discs porosity 10, 21 and $31 \%$ respectively. This indicates that the reduction of saline water concentration is directly proportional to volumes of pottery discs and inversely proportional to pottery porosity percentage, as shown in Fig.5.

Reduction of saline water concentration is attributed to adsorption of $\mathrm{Na}^{+}$on clay minerals found in pottery mixtures. Hence, increasing the clay minerals percentage in pottery mixture shall increase the ability of $\mathrm{Na}^{+}$adsorption. 


\section{Water concentration versus pottery porosity}

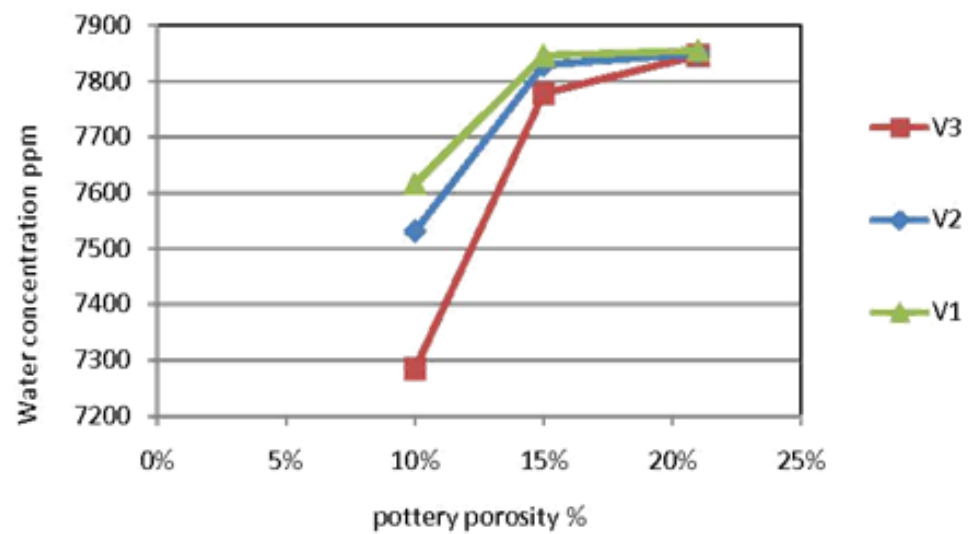

Fig. 5 Effect of pottery dripper porosity of total dissolved salts (7863 ppm).

\section{Hydraulic characteristics of pottery drippers:}

Pottery drippers for $\left(10 \%\right.$ pottery porosity and volume $\left.49 \mathrm{~cm}^{3}\right)$ are tested under operating pressure heads $0.5,0.75$ and 1 bar. The flow rate has increased from 0.75 , and 1.5 to $1.95 \mathrm{l} / \mathrm{s}$. With respect to the pottery discs with volume $31.4 \mathrm{~cm}^{3}$, the flow rate has increased from, 0.53 , and 0.97 to $1.41 \mathrm{l} / \mathrm{s}$. For volume of pottery discs $16.5 \mathrm{~cm}^{3}$, the flow rate has increased from, 0.39, and 0.755 to $1.121 / \mathrm{s}$, Fig. 6 .

pottery drippers flow rate under various operating head.

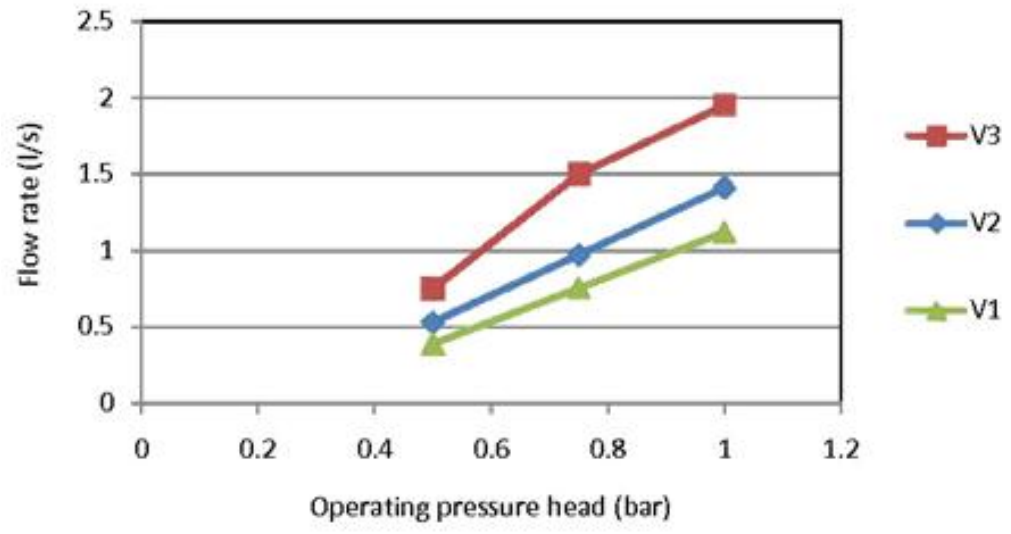

Fig. 6 Effect of pressure head on pottery dripper flow rate (porosity $10 \%$ ).

The increase in the flow rate is associated with increase in the flow area .The flow area is determined according to rubber ring inside area, where the last flow rates are appropriate for drip irrigation systems.

Table.2. Effect of operating pressure head on pottery drippers flow rate.

\begin{tabular}{|c|c|c|c|c|c|c|c|c|c|c|c|}
\hline \multicolumn{3}{|c|}{$31 \%$} & \multicolumn{5}{|c|}{$21 \%$} & \multicolumn{3}{|c|}{$10 \%$} & $\mathbf{P}$ \\
\hline 49 & 31.4 & 16.5 & $\mathrm{~V}$ & 49 & 31.4 & 16.5 & $\mathbf{V}$ & 49 & 31.4 & 16.5 & 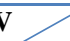 \\
\hline 19.4 & 18.2 & 17.9 & 0.5 & 1.34 & 0.99 & 0.79 & 0.5 & 0.75 & 0.53 & 0.39 & 0.5 \\
\hline 28.3 & 27.9 & 27.4 & 0.75 & 2.53 & 1.8 & 1.46 & 0.75 & 1.5 & 0.97 & 0.755 & 0.75 \\
\hline 38.3 & 37.7 & 37 & 1 & 3.72 & 2.51 & 2.13 & 1 & 1.95 & 1.41 & 1.12 & 1 \\
\hline
\end{tabular}

Where:

$$
\begin{aligned}
& \text { P: Porosity percentage (\%), } \\
& \text { H: } \quad \text { Operating head pressure (bar). }
\end{aligned}
$$

V: $\quad$ Pottery disc volume $\left(\mathrm{cm}^{3}\right)$, and

Pottery drippers for $\left(21 \%\right.$ pottery porosity and volume $\left.49 \mathrm{~cm}^{3}\right)$ are tested under operating pressure heads $0.5,0.75$ and 1 bar. The flow rate has increased from, 1.34, and 2.53 to $3.72 \mathrm{l} / \mathrm{s}$. With respect to pottery discs with volume $31.4 \mathrm{~cm}^{3}$, the flow rate has increased from 0.99 , and 1.8 to $2.51 \mathrm{l} / \mathrm{s}$. For volume of pottery discs $19.5 \mathrm{~cm}^{3}$, the flow rate has increased from, 0.79, and 1.46 to $2.13 \mathrm{l} / \mathrm{s}$, Fig. 7 .

The increase in the flow rate is associated with the increase in the flow area. The flow area is determined according to rubber ring inside area, where the last flow rates are appropriate for drip irrigation 
systems. Pottery drippers for ( $31 \%$ pottery porosity and volume $\left.49 \mathrm{~cm}^{3}\right)$ are tested under operating pressure heads $0.5,0.75$ and 1 bar. The flow rate has increased from, 19.4, and 28.3 to $38.3 \mathrm{l} / \mathrm{s}$. With respect to pottery discs with volume $31.4 \mathrm{~cm}^{3}$, the flow rate has increased from, 18.2, and 27.9 to $37.7 \mathrm{l} / \mathrm{s}$. For volume of pottery discs $19.6 \mathrm{~cm}^{3}$, the flow rate has increased from, 17.9, and 27.4 to $371 / \mathrm{s}$, Fig. 8 .

\section{pottery drippers flow rate under various operating head.}

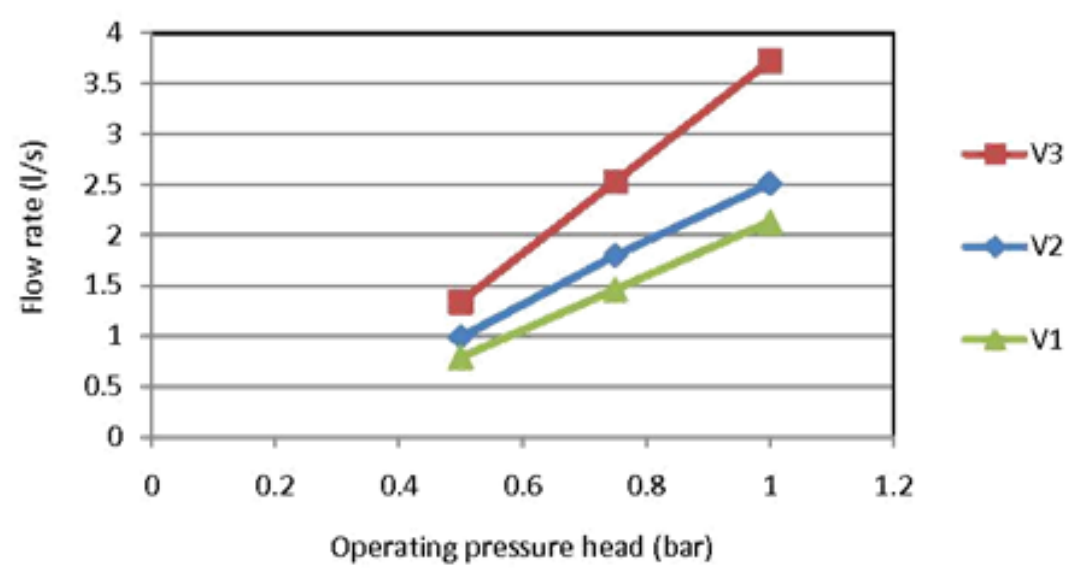

Fig. 7 Effect of pressure head on pottery dripper flow rate (porosity $21 \%$ ).

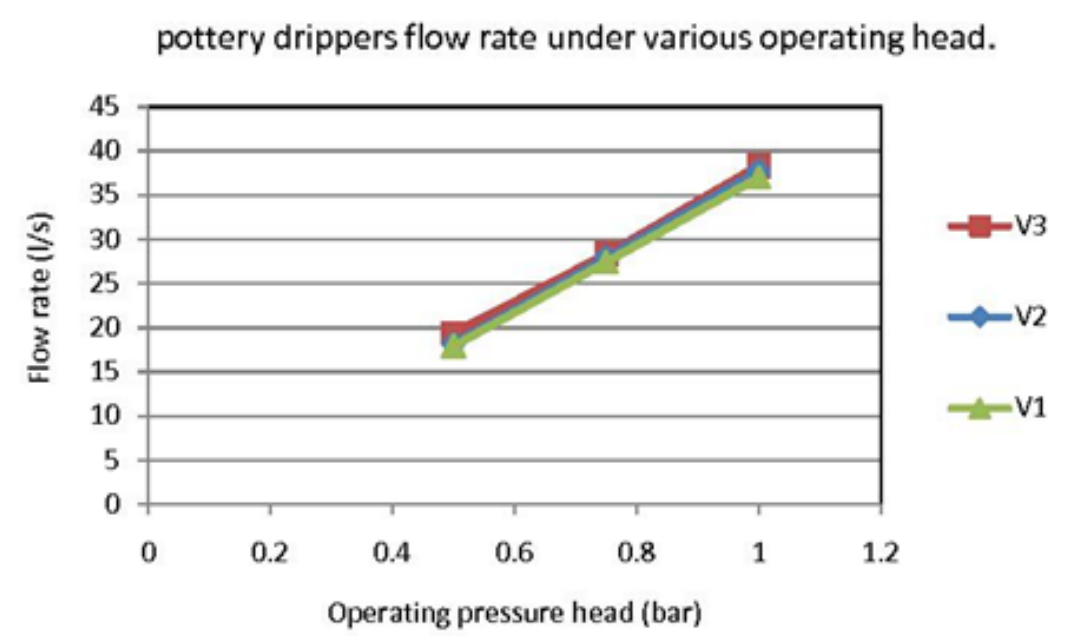

Fig. 8 Effect of pressure head on pottery dripper flow rate (porosity $31 \%$ ).

The increase in the flow rate is associated with the increase in the flow area. The flow area is determined according to rubber ring inside area, where the last flow rates are appropriate for bubbler irrigation systems, and the difference between the three used volumes is so weak. Flow rates versus operating heads, porosity $\%$ and discs volume are shown in Table. 2 .

It is evident that the increase in the flow rate is associated with the increase in Pottery porosity. On the other hand, the efficiency of water salinity reduction decreased, because of the decrease in the percentage of clay minerals weight in pottery mixture, leading also to a decrease in the cations adsorption process.

\section{Some physical characteristics of pottery discs:}

Pottery porosity percentage increases with the increase of saw dust in pottery mixtures; pottery porosity is $10.47 \%, 21 \%$ and $31 \%$ for additional saw-dust

$5 \%, 10 \%$ and $15 \%$ of mixture weight respectively. This is shown in Figs.9, 10 and 11, 


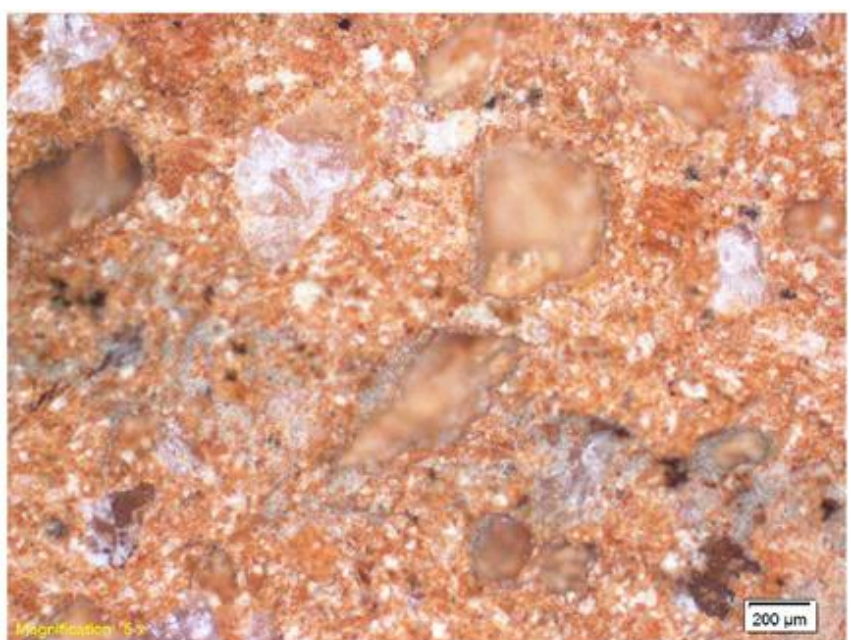

Fig. 9 SEM image shows the surface of pottery disc (porosity $10 \%$ ).

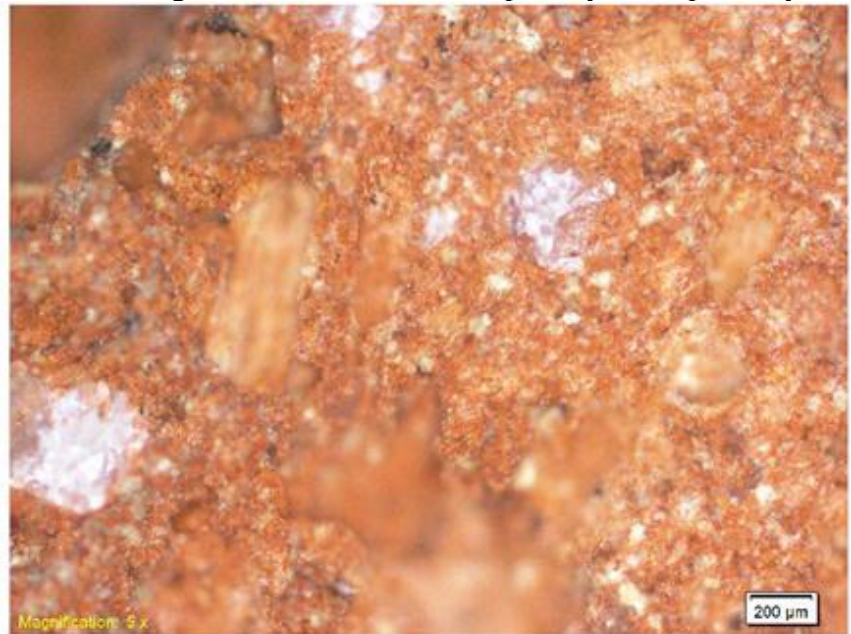

Fig. 10 SEM image shows the surface of pottery disc (porosity $21 \%$ ).

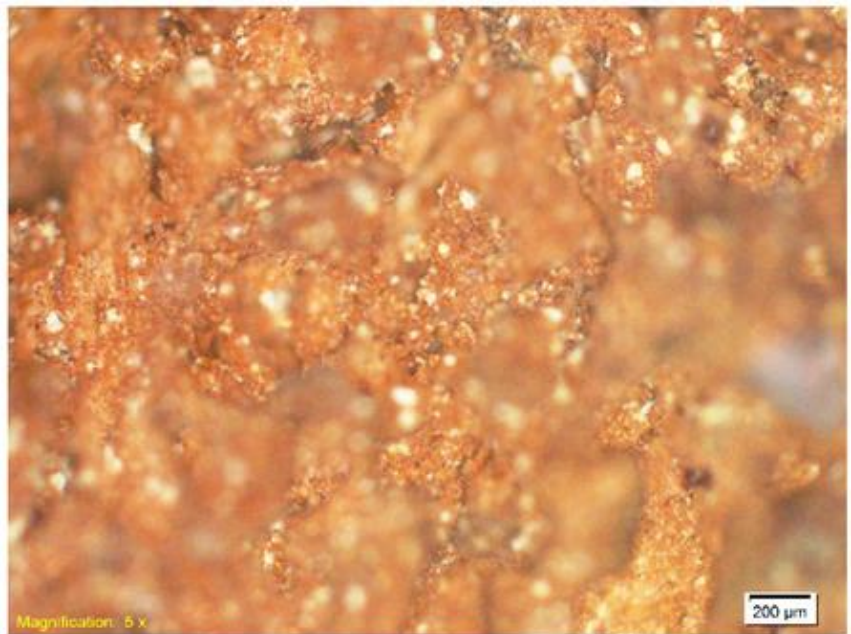

Fig. 11 SEM image shows the surface of pottery disc (porosity $31 \%$ ).

Which indicate the difference of porosity percentage and random shapes of the pottery discs through use of electronic microscope for pottery disc sections in addition to the optical photo view of the pottery discs that show the quantity of porosity (Black sectors) and clay minerals, sand (pink sectors) Figs.21,13, and 14. 


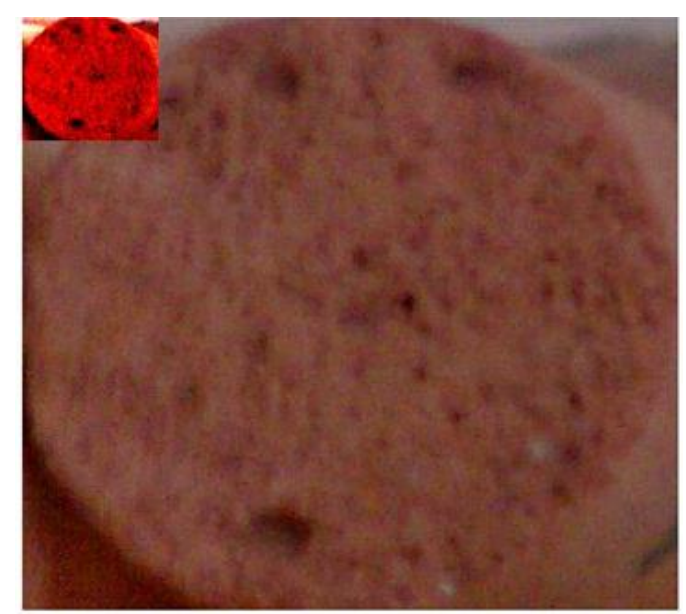

Fig. 12 General image shows the surface of pottery disc (porosity $10 \%$ ).

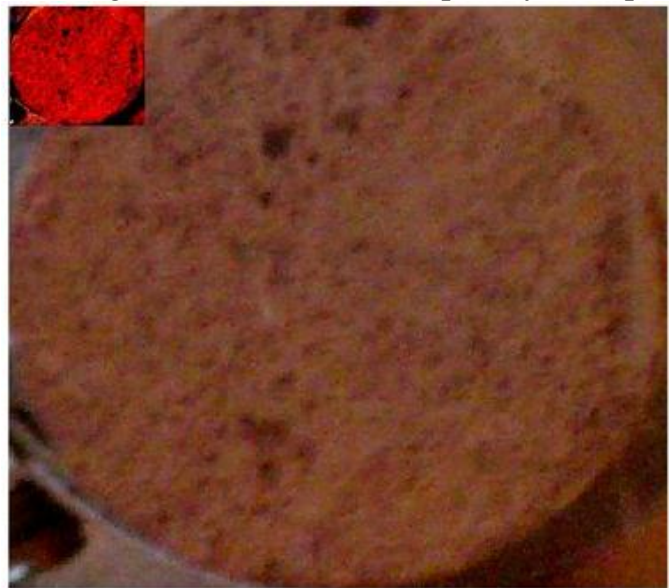

Fig. 13 General image shows the surface of pottery disc (porosity $21 \%$ ).

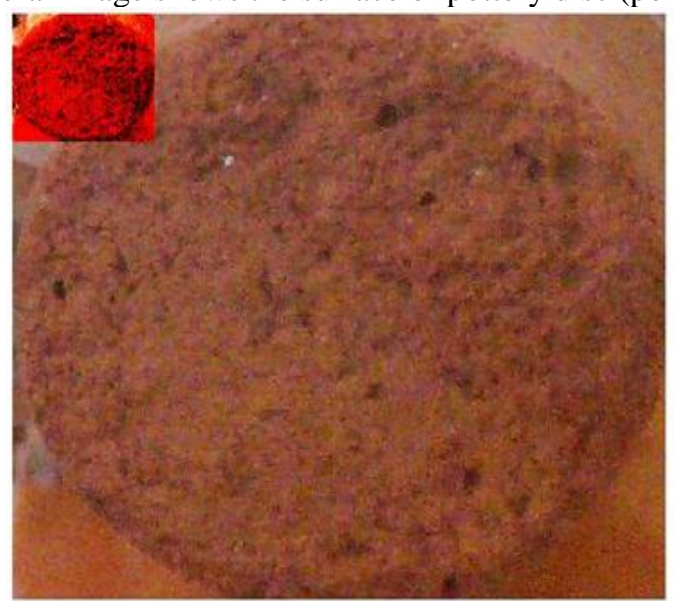

Fig. 14 General image shows the surface of pottery disc (porosity $31 \%$ ).

Water adsorption for P1, P2 and P3 are 60, 20 and 31\% respectively; and the bulk density is $2.24,1.7,1 \mathrm{~g} / \mathrm{cm}^{3}$ respectively. Fig.15. Table.3.

Table.3. Physical characterizes of Pottery disc versus porosity.

\begin{tabular}{lccc}
\hline Items & $\mathbf{P}_{\mathbf{1}}(10.47 \%)$ & $\mathbf{P}_{\mathbf{2}}(21 \%)$ & $\mathbf{P}_{\mathbf{3}}(31 \%)$ \\
\hline Water absorption (\%) & 60 & 20 & 13 \\
\hline Bulk density $\left(\mathbf{g} / \mathbf{c m}^{3}\right)$ & 1.3 & 0.85 & 0.75 \\
\hline Drying deflators $(\%)$ & 10.6 & 10.3 & 10 \\
\hline Burning deflators $(\%)$ & 1.1 & 3.8 & 2.6 \\
\hline Total deflators $(\%)$ & 11.7 & 17.1 & 12.6 \\
\hline
\end{tabular}




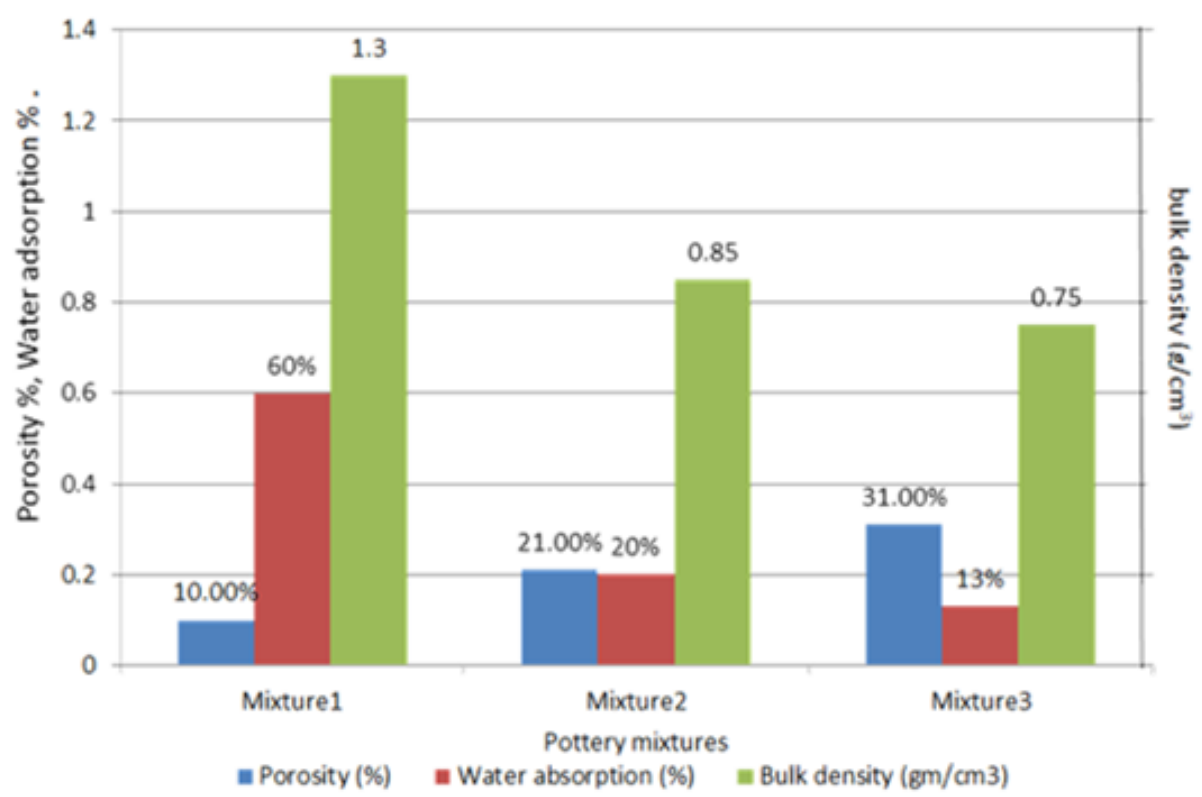

Fig. 15 Effect of different organic matter content on pottery discs physical properties.

\section{RD analysis for three type of pottery mixture:}

By analysis three types of Pottery mixture the results as follow

a) Pottery porosity $(\mathbf{1 0 \%})$ :

The mineralogical composition show that the studied sample consists mainly of quartz, albeit and muttile, moreover, illite mineral presets as trace in XRD. Fig. (16).

b) Pottery porosity (21\%):

From the mineralogical composition of the studied sample it can be concluded that quartz, muttile and albeit, are the primary minerals no evidence for precedence secondary mineral moreover, illite mineral presets as trace in XRD. Fig. (17).

c) Pottery porosity $(31 \%)$ :

The mineralogical composition by XRD show that quartz, mullite and muttile, are primary minerals represented the main constituted of the studied sample, on the other hand, albite were observed as secondary mineral. Fig. (18).

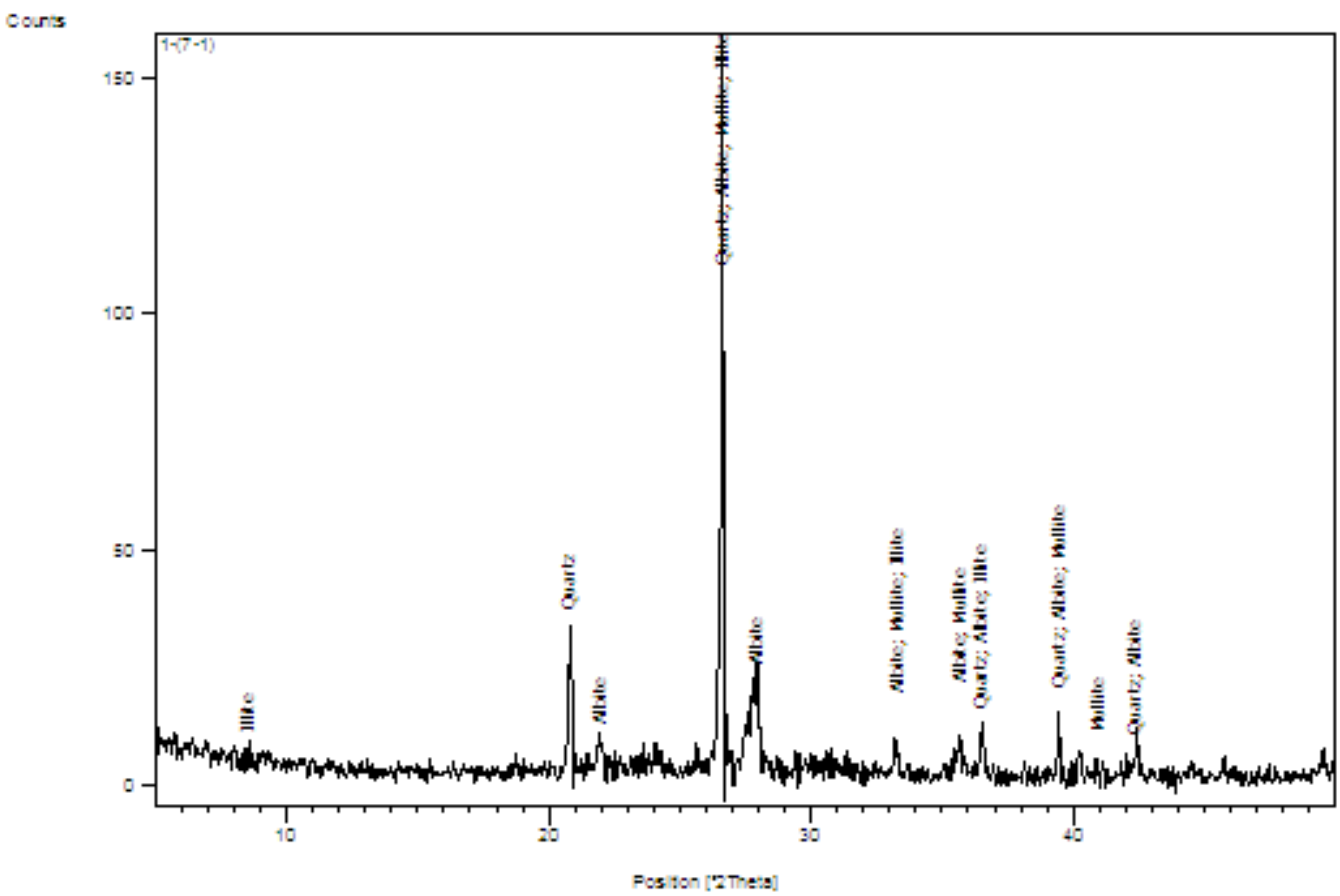

Fig. 16 XRD analysis shows the mineralogical composition of pottery disc (porosity $10 \%$ ). 


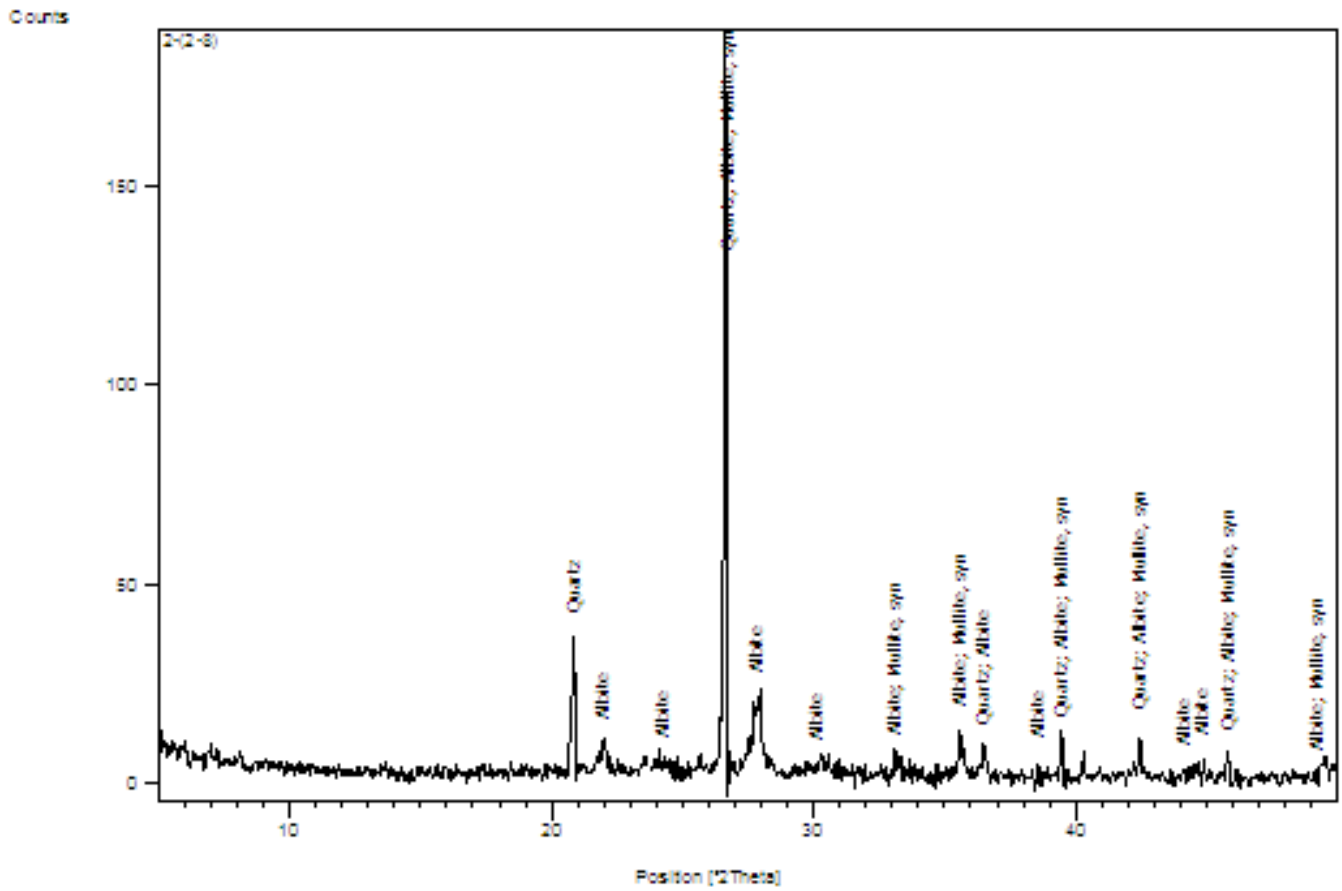

Fig. 17 XRD analysis shows the mineralogical composition of pottery disc (porosity $21 \%$ ).

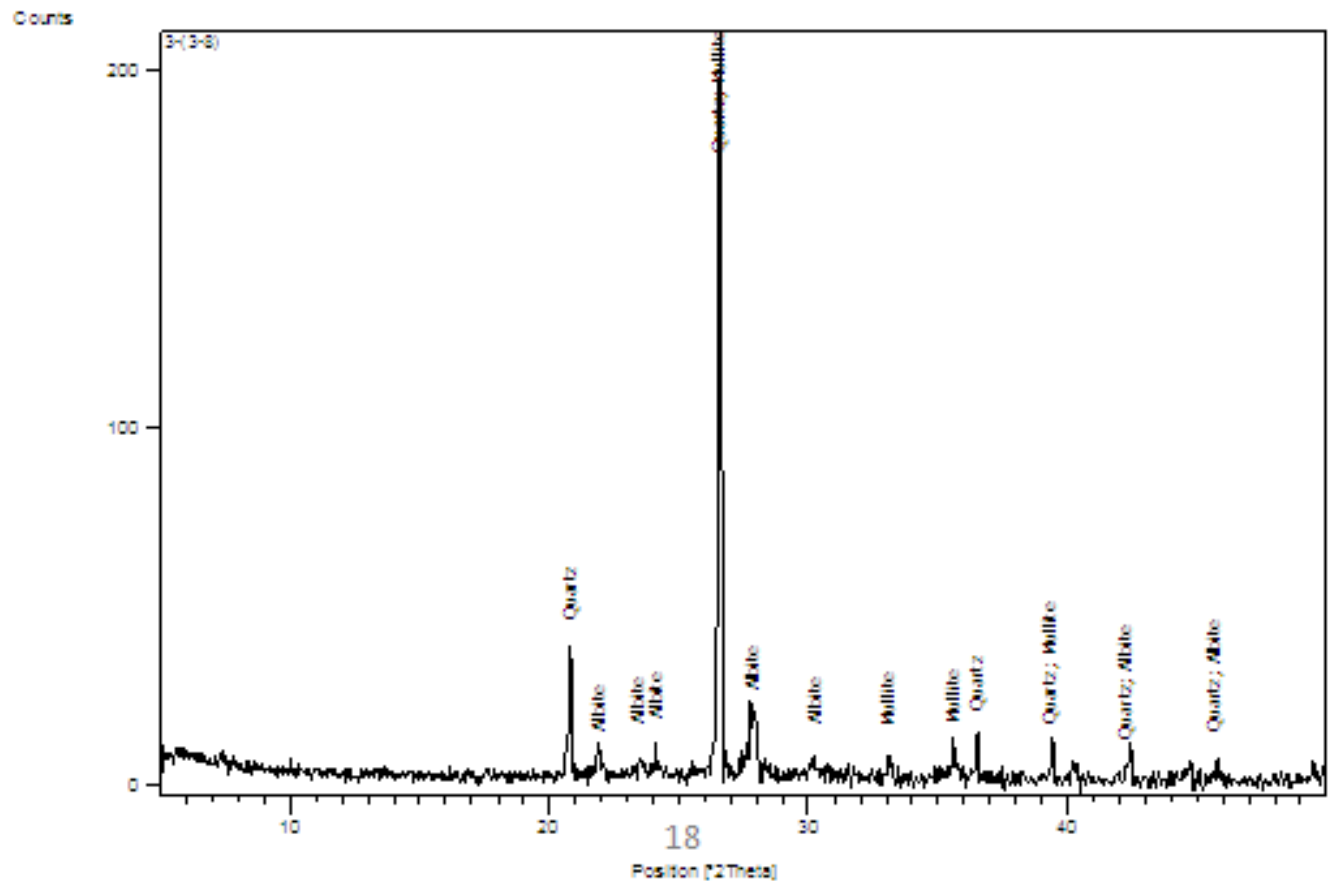

Fig. 18 XRD analysis shows the mineralogical composition of pottery disc (porosity $31 \%$ ).

\section{Conclusion}

Pottery dripper is a new dripper technology for saline water; it can reduce water salinity by $750 \mathrm{ppm}$. $\mathrm{PD}$ is thereupon suitable for using saline water and rationalizing the saline water usage. This study underscores the advantages of both the pottery media (clay minerals) and irrigation nets to conveyance water to plants. A new dripper is used as a filter for small water units. Pottery porosity is a basic factor for reduction of water salinity and also flow rate.

For porosity $\mathrm{P}_{1}(10 \%)$ of pottery dripper, under operating pressure head 1 bar, the discharge ranged from $1.2 \mathrm{l} / \mathrm{s}$ to $1.95 \mathrm{l} / \mathrm{s}$. For porosity $\mathrm{P}_{2}(21 \%)$ of pottery dripper, under operating pressure head $1 \mathrm{bar}$, the discharge ranged from $2.13 \mathrm{l} / \mathrm{s}$ to $3.72 \mathrm{l} / \mathrm{s}$. For porosity $\mathrm{P}_{3}(31 \%)$ of $\mathrm{PD}$, under operating pressure head $1 \mathrm{bar}$, the discharge ranged from $17.9 \mathrm{1} / \mathrm{s}$ to $19.4 \mathrm{l} / \mathrm{s}$. Saline water concentration decreased from $6154 \mathrm{ppm}$ to 5840,5806 and 5440ppm using the PD with porosity 10, 21 and 31\% respectively. Saline water concentration decreased 
from 7149ppm to 7106, 7013 and 6979 ppm using the PD with porosity 10, 21 and $31 \%$ respectively; and finally saline water concentration decreased from $7863 \mathrm{ppm}$ to 7846,7778 and $7285 \mathrm{ppm}$ using the PD with porosity 10,21 and $31 \%$ respectively.

It is evident that the increase in the flow rate is associated with the increase in Pottery porosity. On the other hand, the efficiency of water salinity reduction has decreased, because of the decrease in the percentage of clay minerals weight in pottery mixture, leading also to a decrease in the cations adsorption process . Prototypes of pottery drippers are designed and manufactured from local and environmental material, as one of the models in the Agricultural Waste Recycling Industry.

\section{Reference}

[1]. Batchelor, A. C, Lovella C. and Muratab M. 1996, Simple micro-irrigation techniques for improving irrigation efficiency on vegetable gardens, Agricultural Water Management, Volume 32, Issue 1, November 1996, pp.37-40.

[2]. Bhatt N., B. Kanzariya , A. Motiani and B. Pandi (2013). An Experimental Investigation on Pitcher Irrigation Technique on Alkaline Soil with Saline Irrigation Water, International Journal of Engineering Science and Innovative Technology (IJESIT), ISSN: 2319-5967.

[3]. Keller, J. and D. Karmeli (1975). Trickle irrigation design rain bird sprinkler manufacturing crop. Glendor Calfi, 91740 USA: $24-$ 26.

[4]. Mathai M.P. and A. Simon, 2004Water diffusion through pottery discs of varying porosity, Journal of Tropical Agriculture 42 (1-2): 63-65.

[5]. Siyal A.A. S and T.H. Skaggs, (2009). Measured and simulated soil wetting patterns under porous clay pipe sub-surface irrigation, Agricultural Water Management 96 (2009) : 893-904.

[6]. Vasudaven P, B. Kaphaliy, R. K. Srivastava, M. Tandon S. N. Singh and P. K. Sen, 2011, Buried clay pot irrigation using saline water, Journal of scientific \& Industrial Research, Vol. 70, pp. 653-655. 